\title{
İnönü Evlilik Tutum Ölçeği: Geçerlik ve Güvenirlik Analizleri
}

\author{
Ferhat BAYOĞLU ${ }^{1}$ \\ Abdullah ATLI ${ }^{2}$
}

Geliş Tarihi: 16.05.2014 Kabul Tarihi: 31.10.2014

\section{$\ddot{\mathbf{O z}}$}

Bu araştırmanın amacı genç yetişkinlerin evliliğe yönelik tutumlarını ölçmek amacı ile bir ölçek geliştirmektir. Katılımcılar 2013-2014 akademik yılında Türkiye'deki üç farklı üniversitede öğrenim gören 696 üniversite öğrencisinden (384 k1z ve 312 erkek) oluşmaktadır. Katılımcıların yaşları 18 ile 26 yaşları arasında değişmektedir. Ölçeğin güvenirliliğini belirlemek için, Cronbach alfa, test-tekrar test, testi yarılama analizleri yapıldı ve yapı geçerliği için doğrulayıcı ve açımlayıcı faktör analizleri gerçekleştirildi. Sonuçlar, İnönü Evlilik Tutum Ölçeği'nin (İETÖ) toplam varyasın \% 36'sını açıklayan tek faktörlü bir yapıda olduğunu göstermektedir. Ölçeğin güvenirlik değerleri .87 ve .90 değerleri arasında bulunmuştur. $\mathrm{Bu}$ bulgular, geçmiş araştırmaların bulguları 1şı̆̆ında tartışıldı ve sonraki çalışmalar için araştırmacılara öneriler verildi.

Anahtar kelimeler: evlilik, genç yetişkinlik, üniversite ögrencileri, evlilik tutumu.

\footnotetext{
${ }^{1}$ Ferhat Bayoğlu, Anadolu Üniversitesi, fbayoglu@anadolu.edu.tr

${ }^{2}$ Yrd. Doç. Dr. Abdullah Atli, İnönü Üniversitesi, Eğitim Bilimleri Bölümü, abdullah.atli@inonu.edu.tr
} 


\title{
Inonu Marriage Attitude Scale: Validity and Reliability Analysis
}

\begin{abstract}
The purpose of this research is to develop a scale to measure the attitude of young adults about marriage. The participants consist of 696 undergraduate students (384 female and 312 male) which are educating at three different universities in 2013-2014 academic year in Turkey. The age of the participants ranged 18-26 years. To determine the reliability of the scale, Cronbach alpha, test-retest, split-half reliability coefficients were conducted and for construct validity, exploratory and confirmatory factor analysis were performed. The results showed that Inonu Marriage Attitude Scale (IMAS) was comprised of one factor with a total variance of $\% 36.77$. The reliability of the scale was found between .87 and .90 . These findings were discussed in the light of previous studies and suggestions were given to researchers for further studies.
\end{abstract}

Keywords: marriage, young adulthood, college students, marital attitude. 


\section{Giriş}

Dünyanın hiç bir yerinde ailesiz bir topluma rastlanmamıştır ve tarihsel olarak en eski sosyolojik kurumlardan biri olan ailenin sağlıklı bir yapıda olması, toplumların refahı, mutluluğu ve güçlülüğü ile doğrudan ilişkili olarak görülmüştür (Koçinoğlu, 1991). Evlilik ise, günümüzde yasalar ve toplumsal kurallara göre aile kurumuna hukuki bir nitelik kazandıran ve yeni bir aile kurmanın tek ve meşru yolu olarak kabul edilen bir kurumdur (Kayhan ve Seçkin, 1999).

İnsanların yaşamları boyunca almış oldukları bazı önemli kararlar vardır ve bu kararlar yaşamlarının büyük çoğunluğunu etkileyen türden kararlardır. Bu anlamda evlilik de insan yaşamında çok önemli bir dönüm noktasını, evlilik kararı ise yaşamın en zor ve en önemli kararlarından birisini oluşturmaktadır. Toplumun hangi kesiminden olursa olsun bireyler, belli bir yaşa geldiklerinde hayatı bir başkasıyla paylaşma ihtiyacı duyarlar ve kendilerine uygun bir eş bulup evlenirler (Ondaş, 2007).

Türk Medeni Kanunu'na göre evlilik, tam ve sürekli bir hayat ortaklığı yaratmak üzere ayrı cinsiyetteki iki kişinin hukuken makbul ve geçerli birleşmesi olup, sosyal, ahlaki ve aynı zamanda hukuki bir kurumdur (Keklik ve Yıldırım, 2012). Evlilikle ilgili olan tanımlar bize evlenmenin, yeni bir aile kurmada ön koşul olduğunu göstermektedir ve evlenme ile aile kurumunun oluşturulması, evliliğe sosyal bir nitelik kazandırmaktadır (Kayhan, 2011; Kayhan ve Seçkin, 1999).

Bireylerin evlenme nedenleri incelendiğinde; ekonomik etkenlerin, yalnızlıktan kurtulmanın, cinsel doyumun yasal şekilde sağlanmasının, statü ve bağımsızlık kazanmanın ve sahiplenme duygusu gibi etkenlerin etkili olduğu görülmektedir (Güleç, 2013; Özgüven, 2009). Bir yaşam biçimi olarak evlilik olgusuna, birbirinden çok farklı kültürlerde evrensel düzeyde rastlanması, evliliğin kişisel ve toplumsal çeşitli işlevleri yerine getirmesinden kaynaklanmaktadır (Güleç, 2013; Kayhan, 2011).

Evliliğin işlevi ve önemini ortaya koymak amacı ile bireylerin niçin evlendiği konusu araştırmacılar da tarafından incelenmiştir. Evlilik ve eş seçme konusunda üniversite öğrencileri ile yapılan bir çalışmada (Özgüven, 1994; akt. Özgüven, 2009), evliliğin neden gerekli olduğu sorusunu öğrencilerin \% 68'i, yaşantılarını bir başkasıyla paylaşmak için şeklinde cevaplandırmışlardır. Bu sorunun seçenekleri arasında bulunan, çocuk sahibi olmak, ileride yalnız kalmamak, evlilikte cinsel ilişkiye izin verilmesi ve ailenin baskısı gibi 
cevapların yüzdesi ise daha düşük çıkmıştır. Öğrencilerin \% 10'u ise evliliğin gereğine inanmadıklarını ifade etmişlerdir. Yapılan benzer bir araştırmada da öğrencilerin \% 84'ü yaşamını bir eşle paylaşmak, \% 11'i yalnız kalmamak için ve geleneklerden dolayı, \% 5'i ise çocuk sahibi olmak için evliliği düşündüklerini söylemişlerdir (Durmazkul, 1991; akt. Özgüven, 2009).

Üniversite öğrencilerinin evliliğe ilişkin görüşlerinin incelendiği başka bir çalışmada (Ondaş, 2007), evlilik, hayatı sevilen biriyle paylaşmak için yapılmalıdır görüşü ile birlikte evlilik, çocukların sağlıklı kimlik kazanması için olmalıdır ve evlilik, neslin devamını sağlar görüşleri ile birlikte evlilik, cinselliğin daha rahat yaşanmasını sağlar ve evlilik, daha düzenli bir hayat sağlar görüşlerine araştırmaya katılan katılımcıların yüksek oranda katıldıkları görülmüştür. Üniversite öğrencilerinin eş seçimine ve evliliğe ilişkin görüşlerinin incelendiği başka bir çalışmada ise (Kılıç, Kaygusuz, Bağ ve Tortumluoğlu, 2007), öğrencilerin evliliğe ilişkin yükledikleri anlamlar incelenmiş ve araştırmaya katılan gençlerin evliliği, yeni bir hayat ve düzenli bir yaşam olarak değerlendirdikleri görülmüştür.

Sanayileşme ile yaşanan hızlı toplumsal gelişmeler, geçmiş dönemlerden günümüze evliliğin yapısını değiştirmiş olup bu değişim, evliliğin yapısının incelenmesinin ve değerlendirilmesinin önemini artırmıştır. $\mathrm{Bu}$ anlamda aile ve aile yapısının iyi bir şekilde değerlendirilmesi, aile içindeki zorlukların, problemlerin, çocuklar ve ebeveynler arasındaki sorunların anlaşılması ve evlilik ilişkisinin değerlendirilmesi açısından önemlidir (Güleç, 2013).

Küresel değerlerin ön plana çıktığı ve hızlı bir değişimin yaşandığı bu dönemde, bilgi ve iletişim teknolojilerindeki gelişmeler, toplumsal yapıların değişmesine ve yeniden şekillenmesine neden olmuştur. Bilgi çağında yaşanan bu değişimler, 20. yüzyılın ikinci yarısından itibaren Avrupa ülkelerinin yanı sıra diğer ülkelerde de ailenin oluşumunda, çözülmesinde ve tekrar oluşma süreçlerinde dikkat çekici değişimlerin yaşanmasına neden olmuştur (Kotowska ve diğ., 2010; akt. Bener ve Günay, 2012). Yaşanan bu hızlı değişim süreci, evlilik ve aile kurumu ile ilgili de bazı yenilik ve değişimleri de birlikte getirmiştir. Aile ve evlilik yapısında meydana gelen değişmelerin de aynı şekilde toplumsal yapıyı etkilemesi ve değiştirmesi söz konusu olabilmektedir. İlk evlenme yaşının yükselmesi, evlilik sayısında ciddi azalmalar meydana gelirken; boşanma oranlarının önemli ölçüde artması gibi yaşanan değişimler, toplumsal yapıyı ve özellikle de o toplumu oluşturan bireylerin evlilik ve aile kurumuna ilişkin tutumlarını etkileyebilmektedir. 
Türkiye İstatistik Kurumu'nun (TÜIK) 2008-2013 yılları arası evlenme ve boşanma oranları ile ilgili verileri incelendiğinde, evlenen çift sayısında son 5 yılda yüzde 5,95 oranında azalma meydana geldiği görülmektedir. 2008 yılında binde 9,03 olan kaba evlenme hızı da 2012 y1lında binde 8,03'e gerilemiştir. 2012'de evlenen çiftlerin sayısı ise 603 bin 751'e gerilemiştir. 2013 yılında ise bu sayı önceki yıla göre yüzde 0,6 azalarak 600 bin 138'e düşmüştür. Veriler incelenmeye devam edildiğinde, boşanan çiftlerin sayısının 2013 yılında, bir önceki yıla göre \% 1,6 artarak 125 bin 305'e yükseldiği görülmektedir. 2013 y1lı içinde gerçekleşen boşanmaların \% 40,3’ü evliliğin ilk 5 yılı içinde, \% 21,5’i ise evlilik süresi 6-10 yıl arası olan çiftlerde gerçekleşmiştir. $\mathrm{Bu}$ bilgilerden hareketle özetle, son yıllarda Türkiye'de evlenme sayısında düşüş görülürken, boşanmalarda ise tersi bir durumun olduğu söylenebilir.

Yine TÜİK verilerine göre ortalama ilk evlenme yaşı, 2008 y1lında erkekler için 26,2, kadınlar için 22,9' dur. 2012 yılı verilerine göre, ortalama ilk evlenme yaşı erkekler için 26,7, kadınlar için 23,5'dur. 2013 yılında ise bu değerlerin erkekler için 26,8'e, kadınlar için ise 23,6'a yükseldiği görülmektedir. Ortalama ilk evlenme yaşında son yıllarda hem erkekler de hem de kadınlarda artış olması ile birlikte, burada dikkat çeken başka bir önemli nokta, ilk evlenme yaşının özellikle genç yetişkinlik dönemi olarak adlandırılan döneme denk geliyor olmasidir.

Üniversite öğrencileri ile yapılan bir çalışmada (Ondaş, 2007), araştırmaya katılan öğrencilerin \%52.2'sinin en uygun evlenme yaşını 26-29 yaşları; \%37.1'inin ise 22-25 yaşları olarak gördüğü belirtilmiştir. Üniversite öğrencilerinin evlilik konusundaki görüş ve düşüncelerinin incelendiği başka bir çalışmada (Türkaslan ve Suleymanov, 2010), üniversite öğrencilerinin en uygun evlenme yaşını 22-25 yaş aralığı olarak belirtmişlerdir. Kılıç ve diğerleri (2007), üniversite öğrencilerinin eş seçimine ve evliliğe ilişkin görüşlerinin incelendiği çalışmalarında ise, araştırma kapsamına alınan gençlerin büyük çoğunluğunun (\% 56.6), evlenme yaşı olarak 25-28 yaş arasını uygun bulduklarını belirtmişlerdir. Ekşsi’nin (2005) evliliğe hazırlık aşamasındaki karı-koca adaylarının evlilik ve anne-baba olma üzerine düşünceleri konulu çalışmasında evlenmek üzere olan katılımcıların yaşları incelendiğinde; ilk sırada \% 42 ile 20-24 yaş grubundakiler yer almaktayken, \% 40 oranıyla ikinci sırada 2529 yaş grubundakiler yer almaktadır.

Bu bilgiler doğrultusunda evlilik kararına en yakın yaş grubunu oluşturan, 18-30 yaşları genç yetişkinler için önemli bir dönüm noktasını oluşturmaktadır. Diğer gelişim dönemlerinde 
olduğu gibi, birden fazla ve önemli değişikliklerin yaşandığı bu dönemde karşı cinsle yakın ilişkiler kurma dönemin en önemli gelişim görevlerinden birisi olarak karşımıza çıkmaktadır. $\mathrm{Bu}$ dönemde gençler, Erikson’un psiko-sosyal gelişim kuramına göre yakınlığa karşı yalıtılmışlık/yalnızlık dönemi içerisinde bulunmaktadırlar ve kurama göre genç yetişkinlik dönemi, genel hatlarıyla geç ergenlikten orta yaşlara kadar olan, aile kurma ve kur yapma dönemini kapsamaktadır. Eğer arkadaşlarla veya eşle yakınlık kurulamazsa, Erikson’a göre genç, kimseyle sevgi ve paylaşma yaşamaksızın yalnız olur ve yalıtılmışlık hisseder (Elkind, 1970; Erikson, 1977). Havighurst'un gelişim görevlerine göre de, bireyler 18-30 yaş arasında genç yetişkinlik dönemindedirler ve bu dönemde eş seçme, aile kurma, bir partner ile yaşamayı öğrenme, bağımsız bir ev kurma, aile kurma gibi gelişim ödevlerini yerine getirmeleri gerekir (Seiffge-Krenke ve Gelhaar, 2008).

Evlilik ve aile kalıplarında yaşanan değişim süreci genç yetişkinleri, hem çocukluk hem de gençlik dönemlerindeki planlarını ve tutumlarını etkileyebilmektedir. Evlilik ve aile hayatına ilişkin yaşanan bu değişimlerin, gençlerin evliliğe ilişkin bazı olumsuz tutumlar geliştirmelerine neden olabileceği düşünülmektedir. Yaşamları boyunca neredeyse bütün insanların evlendikleri göz önünde bulundurulacak olursa, evlilik tutumundaki bu değişiklikler dikkate alınması gereken önemli bir olgu olarak karşımıza çıkmaktadır (Braaten ve Rosen, 1998). Örneğin önceki yıllar ile karşılaştırıldığında, bireylerin daha geç evlenmekte olduğu ve boşanma oranlarında da ciddi artışlar olduğu görülmektedir. Son derece yerleşik olan pozitif ve negatif evlilik tutumları, ilişkiler ile ilgili inançları ve ilişki içerisindeki davranış şekilleri ve evlenmeye karar verme gibi daha sonraki evlilik ile ilgili davranışları etkilemektedir (Rosen ve Park, 2013).

Ülkemizde evlilik öncesi ilişki geliştirme programlarının son yıllarda popülerlik kazanmaya başlamasına rağmen (Kalkan, 2002; Kalkan ve Kaya, 2007; Yılmaz, 2009; Yalçın, 2010; Duran, 2010), evlilik öncesinde genç yetişkinlerin evliliğe ilişkin tutumlarını belirlemeye yönelik çalışmaların henüz yaygınlaşmadığı görülmektedir. Sağlıklı bir evliliğin oluşturulması açısından gençleri evlilik, evliliğe ilişkin olumlu tutum, aile yaşamı ve ailede rol paylaşımı gibi konularda bilinçlendirmek oldukça önemlidir. Evliliğe aday gençlerin, evlilik ve evlilik yaşamına ilişkin tutumlarını belirlemek ve bu konuyla ilgili farkındalık ve bilinç düzeylerinin artırmak, gençlerin evliliğe ilişkin tutumlarının ölçülmesini gerektirmektedir. 
İlgili alanyazın incelendiğinde, yurtdışında bireylerin evliliğe ilişkin tutumlarını ölçmek amacıyla geliştirilmiş çeşitli ölçme araçları bulunduğu görülmektedir. $\mathrm{Bu}$ çalışmalardan birisi, Braaten ve Rosen (1998), tarafından geliştirilen “Evlilik Tutumu Ölçeği'dir (Marital Attitude Scale). Bu çalışmada evlilik tutum ölçeği ile heteroseksüel evliliğe yönelik küresel memnuniyet değerlendirilmiştir. Ölçek, 23 madde ve 4'lü likert türünde ve hem evli hem de evli olmayan bireylerin tutumlarını ölçmeye yönelik olarak geliştirilmiştir. Ölçekten alınan yüksek puanlar evliliğe karşı olumlu tutumu göstermektedir. Başka bir çalışmada (Rosen ve Park, 2013) ise, Evlilik Ölçeği (Marital Scale); evliliğe ilişkin niyet, evliliğe yönelik genel tutumlar ve evliliğin farklı yönleri için beklentiler olmak üzere üç ayrı başlık altında ele alınmış ve bu konulara ilişkin olmak üzere üç ayrı ölçeği kapsayan bir çalışma gerçekleştirilmiştir. Evliliğe ilişkin genel tutumları ölçen ve 7’li likert türünde geliştirilen ölçeğin, 10 maddeden ve olumlu tutum, olumsuz tutum ve şüphe/korku olmak üzere üç faktörlü bir yapıdan oluştuğu görülmektedir. Nilforooshan, Navidian ve Abedi (2013) tarafindan yapılan çalışmada ise, Evlilik Tutum Ölçeği'nin (Marital Attitude Scale, (MAS, Braaten ve Rosen, 1998) Farsça'ya uyarlanmasıyla ilgili olarak geçerlik ve güvenirlik analizi çalışması yapılmıştır. Yapılan analiz sonuçları da MAS'ın çok boyutlu bir yapıda olduğunu göstermiştir. Evliliğe yönelik tutum, bireylerin evliliğe yönelik tutumları ve evliliğe yönelik genel tutumlar olarak iki ayrı boyuta sahiptir ve ayrıca genel evlilik tutumu ise; kötümserlik, iyimserlik ve ideal tutum olmak üzere üç farklı tutumu içermektedir.

Yurtiçinde yapılan çalışmalar incelendiğinde, genç yetişkinlerin evliliğe ve aile yaşamına ilişsin görüşlerini değerlendirmek amacıyla yapılmış bir çalışmada (İşmen Gazioğlu, 2006), çalışma kapsamında 109 maddelik bir anket formu geliştirilmiştir. Ankette bulunan ifadeler beş seçenekli Likert ölçek tipine göre derecelendirilmiştir. Başka bir çalışmada (Bener ve Günay, 2012), gençlerin evlilik ve aile yaşamına ilişkin tutumlarını belirlemek amacıyla 22 maddelik bir anket formunun çalışma kapsamında geliştirildiği görülmektedir. Anket beş seçenekli Likert tipine göre hazırlanmıştır. Yurtiçinde gençlerin evliliğe ilişkin tutumlarını belirlemeye yönelik çalışmalar gözlenmiş olsa da, hâlihazırda yapıllmış olan herhangi bir ölçek çalışmasına ise rastlanmamıştır ve gençlerin evliliğe ilişkin bu tutumlarını ölçmeye yönelik yönelik bir ölçme aracına duyulan gereksinimden de hareketle bu çalışma, gençlerin evliliğe ilişkin tutumlarını ortaya koyan geçerli ve güvenilir bir ölçme aracı geliştirmek ve bu ölçme aracının psikometrik özelliklerine ilişkin bilgileri saptamak amacıyla gerçekleştirilmiştir. 


\section{Yöntem}

$\mathrm{Bu}$ bölümde, çalışma grubu, veri toplama araçları ve çalışmaya ilişkin işlem hakkında bilgi verilmiştir.

\section{Çalışma Grubu}

Araştırmaya 2013-2014 eğitim-öğretim döneminde Atatürk Üniversitesi, İnönü Üniversitesi ve Anadolu Üniversitesinin farklı fakültelerinde öğrenim gören 723 öğrenci katılmıştır. Çalışma grubunun seçiminde, öğrenimine devam eden farklı fakülte ve bölüm düzeyinde öğrencinin katılımı sağlanmaya çalışılmıştır. Ancak farklı sebeplerden (eksik doldurma, kontrol maddelerini yanlış doldurma, uç değerlere sahip olma) dolayı araştırmada analize 696 öğrenci alınmıştır. Bu 696 öğrencinin 384’ü erkek 312'si kadındır. Ayrıca, test-tekrar test yöntemi için 67 öğrenciden veri toplanmıştır. Araştırmaya katılanların tamamı bekârdır. Araştırmada analize dâhil edilen öğrencilerin yaşları 17-29 arasında değişmektedir ( $\bar{X}$ :20.66, Ss:1.75).

\section{Evliliğe Yönelik Tutum Ölçeğinin Geliştirilmesi}

$\mathrm{Bu}$ çalışma, genç yetişkinlerin evliliğe ilişkin tutumlarını belirlemeye yönelik bir ölçme aracı geliştirmek amacıyla gerçekleştirilmiştir. Geliştirilecek ölçeğe madde havuzu oluşturulmasında öncelikle ilgili alanyazın incelemesi yapılmıştır. Bu aşamanın ardından ölçeğe madde havuzu oluşturulmasında ilgili alanyazın ile birlikte, konu ile ilgili mevcut ölçekler (Braaten ve Rosen, 1998; Rosen vePark, 2013) ve uzman görüşlerinden evliliğe ilişskin tutumlara ilişkin elde edilen bilgiler dikkate alınmıştır. Oluşturulan madde havuzunda, psikolojik danışma ve rehberlik alanında çalışan ve ikisi yüksek lisansını ikisi de doktorasını tamamlamış olan dört uzmanının her bir maddeye ilişkin görüşleri dikkate alınarak gerekli düzenlemeler yapılmıştır. $\mathrm{Bu}$ aşamanın ardından oluşturulan 30 maddelik denemelik ölçek formu, pilot uygulama ile 27 üniversite öğrencisine uygulanmış, maddelerin anlaşılıp anlaşılmadığı, yazım hatalarının var olup olmadığının belirlenmesinin yanı sıra ölçeğin ne kadar sürede doldurulduğu da tespit edilmiştir. Ardından oluşturulan 30 maddelik ölçek formuna iki tane kontrol maddesi (m13: Bu madde için lütfen beşinci seçeneği işaretleyiniz, m22: Bu madde için lütfen üçüncü seçeneği işaretleyiniz) gelişigüzel olarak yanıtlayanları saptamak amacıyla eklenmiş ve çoğaltılarak öğrencilere uygulanmak üzere hazır hale getirilmiştir. 
Ölçek 5’li likert tipindeki derecelemeler; Hiç katılmıyorum (1), Nadiren katıllyorum (2), Biraz katıllyorum (3), Katıllyorum (4) ve Kesinlikle katıllyorum (5) şeklindedir. Elde edilen puanın yüksek olması evliliğe yönelik olumlu tutumu, düşük puan ise evliliğe yönelik olumsuz tutumu ifade etmektedir.

\section{Verilerin Analizi}

Araştırmadan elde edilen veriler SPSS.21 paket programına girilirken, kontrol maddelerine yanlış cevap veren ve eksik işaretleme yaptığı belirlenen 27 ölçek formu analize alınmamıştır. Ayrıca araştırmadan elde edilen verilerin analize uygunluğunu tespit etmek için öncelikle verilerin dağılım özellikleri incelenmiştir. Bunun için öncelikle her madde için uç değerleri tespit etmek için -3 ile $+3 Z$ değeri dikkate alınmış ve 143 veri bu kritere uymadığı için veri setinden çıkarılmıştır. Buna ek olarak, tüm maddelerin çarpıklık ve sivrilik değerlerine bakılmış ve her maddenin çarpıklık ve sivrilik değerlerinin -1.00 ile 1.00 arasında olduğu bulunmuştur. Araştırmanın analiz işlemleri için geriye kalan 553 veri ile analize devam edilmiştir.

\section{Bulgular}

Bu bölümde evlilik tutum ölçeğinin yapısını ortaya çıkarmak için kullanılan açımlayıcı faktör analizi, ortaya çıkan yapıyı doğrulamak için kullanılan doğrulayıcı faktör analizi ve ölçeğin güvenirlik analizlerine ilişkin sonuçlar yer almaktadır.

\section{İETÖ’nün Geçerliğine İlişkin Bulgular}

Yapı geçerliği: Ölçeğin yapı geçerliği için hem açımlayıcı hem de doğrulayıcı faktör analizi yapılmıştır.

a) Açımlayıcı Faktör Analizi: Elde edilen verilerin faktör analizine uygunluğunu belirlemek için Kaiser-Meyer-Olkin (KMO) ve Barlett testi ile test edilmiştir (Gorsuch, 1997). Bu araştırmada açımlayıcı faktör analizi yapılırken şu ölçütler dikkate alınmıştır: 1) Her bir faktörün özdeğerinin en az 1 olması; 2) Her bir faktördeki maddelerin faktör yüklerinin en az .50 değerine sahip olması; 3) Her bir faktöre yüklenen maddelerin anlam ve içerik olarak tutarlı olması ve 4) Maddelerin bulundukları faktörlerdeki yük değerleri ile diğer faktörlerdeki yük değerleri arasındaki farkın .10 ve daha yukarı olması (Çokluk, Şekercioğlu ve Büyüköztürk, 2012). Bu kriterlere uymayan maddeler işlem sırasına göre ölçekten çıkarılmıştır. İlk olarak .50'nin altında faktör yükü olan 6 madde $(9,14,20,28,29,30)$ 
ölçekten çıkarılmıştır. Bu maddeler çıkarıldıktan sonra faktör yükü 50'nin altında olan 2 madde (8 ve 13) daha ölçekten çıkarılmıştır. Bu maddelerin çıkarılmasıyla 12. maddenin faktör yükünün de .50'nin altında yer aldığı belirlenmiş ve bu maddenin de ölçekten çıkarılmasına karar verilmiştir. Elde edilen veriler üzerinde yapılan analizlerde Kaiser-Meyer Olkin değeri .90 olarak kaydedilmiş olup Bartlett's Testi sonucunun $\left[x^{2}=4664.344 d f=190 p\right.$ $<$.001] anlamlı olduğu saptanmıştır. Bu sonuçlara göre, madde örnekleminin faktör analizi için uygun olduğu söylenebilir. Konuyla ilgili değerlendirmelerde, KMO değerlerinin .60 ve yukarı düzeyde olması yeterli kabul edilmektedir (Tabachnick ve Fidell, 2001).

Ayrıca, tek tek her bir maddenin faktör analizine uygunluğu da anti-image korelasyon matrisi yoluyla incelenmiştir. Anti-Image Correlation matrisinde yer alan MSA değerleri en düşük .50 olması gerektiği belirtilmektedir (Field, 2009). Bu değerin .50'nin altında olduğu durumlarda, değişkenler çıkarılarak analiz tekrarlanır. Yapılan analizlerde maddelerin Antiimage Correlation değerlerinin .84 ile .95 arasında değiştiği belirlenmiştir. Buna göre her maddenin faktör analizi için uygun olduğu söylenebilir. Bu tespitin ardından veriler üzerinde temel bileşenler analizi yapılmıştır. Ölçeğin yapı geçerliğini belirlemek için faktör analizi yapılmıştır. Gerçekleştirilen analiz sonucu ölçeğin üç faktörlü bir yapıya sahip olduğu belirlenmiştir. Ancak, birinci faktörün öz değeri ve açıkladığı varyans oranının yüksek iken ikinci faktörde bu değerlerin oldukça düşük çıkması, buna karşılık ikinci faktör ile sonraki faktörlerin öz değeri arasında yakınlık bulunması, ölçeğin tek boyutluluğunu göstermektedir (Lord, 1980; akt. Çokluk ve diğ., 2012). Faktör sayısına sağlıklı karar vermek için öz değer dışında çizgi grafiği (Şekil-1) de incelenmiştir. 


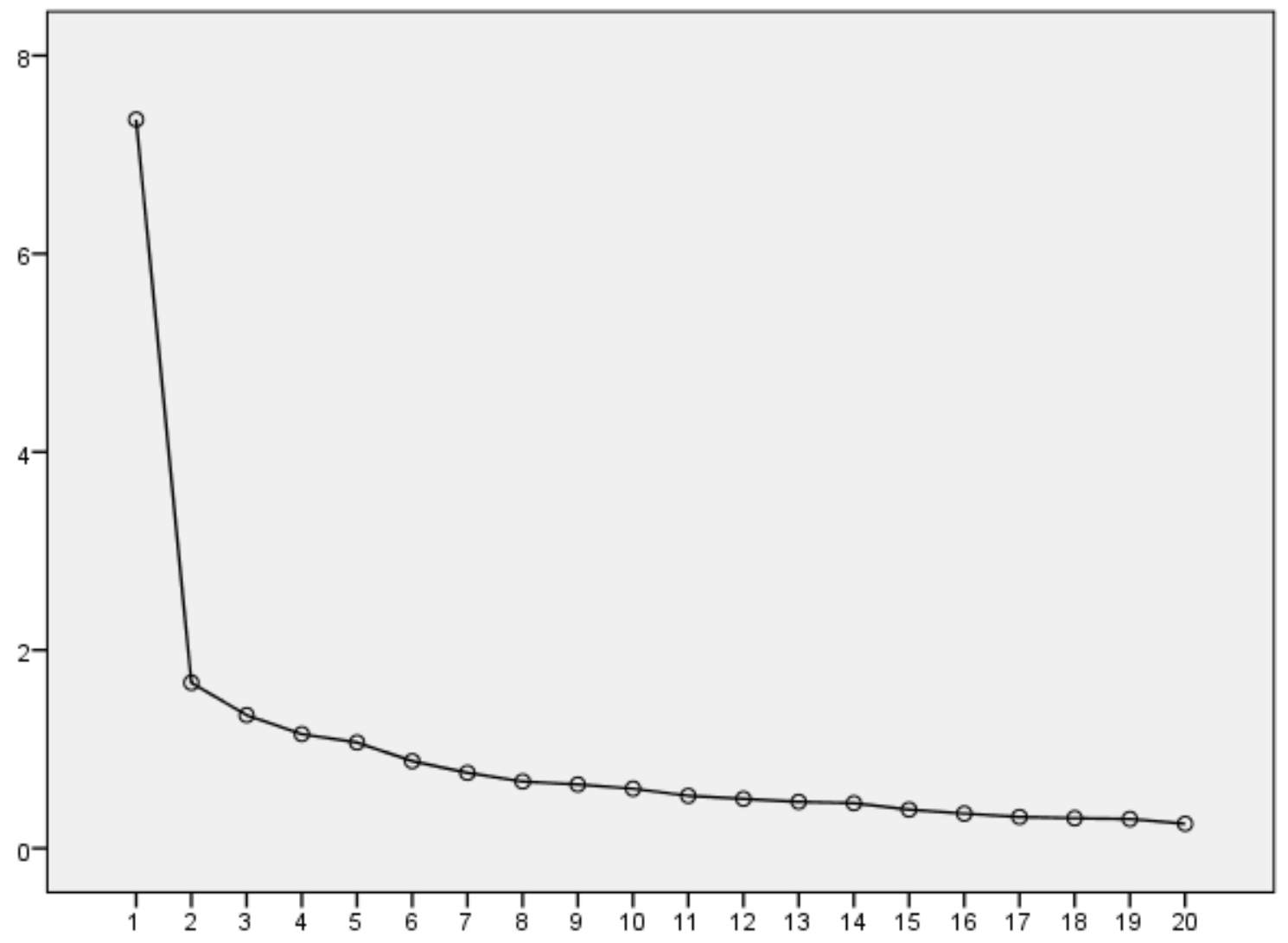

Şekil 1. İETÖ’nün Faktör Analizi

Şekil 1'de kırılma indeksine bakıldığında ölçeğin tek faktörlü bir yapı içerdiği saptanmıştır. $\mathrm{Bu}$ nedenle, tek faktörlü bir yapı için yeniden analizler yapılmıştır ve yapılan analiz sonucunda toplam varyansın \% 36,77'sini açıklayan tek faktörlü bir yapı elde edilmiştir. Tablo 1'de de görüldüğü üzere, İETÖ'nün faktör yapısının toplam varyansın \% 36,77'sini açıklayan ve özdeğeri 7.354 olan tek boyutlu bir yapıda olduğu gözlenmektedir. Tek faktörlü desenlerde açıklanan varyansın \% 30 ve daha fazla olmasının yeterli olduğu belirtilmektedir. (Büyüköztürk, 2012). Ayrıca bu maddelerin faktör yükünün .46 ile .73 arasında değiştiği gözlenmektedir. Faktör yükü ne kadar yüksek olursa o maddelerin açıklayıcılık gücü o derecede iyi kabul edilmektedir. Genel olarak az sayıda maddenin faktör yükü .30 olması kabul edilebilir bir ölçü olarak benimsenmektedir (Worthington ve Whittaker, 2006). Bu veriler, tek faktörlü bir yapıda bu madde yüklerinin kabul edilebilir düzeyde olduğunu göstermektedir. 


\begin{tabular}{|c|c|}
\hline Maddeler & $\begin{array}{l}\text { Faktör } \\
\text { Yükleri }\end{array}$ \\
\hline Madde1 & .73 \\
\hline Madde2 & .71 \\
\hline Madde3 & .68 \\
\hline Madde4 & .66 \\
\hline Madde5 & .63 \\
\hline Madde6 & .62 \\
\hline Madde7 & .62 \\
\hline Madde8 & .61 \\
\hline Madde9 & .61 \\
\hline Madde10 & .60 \\
\hline Madde11 & .59 \\
\hline Madde12 & .58 \\
\hline Madde13 & .58 \\
\hline Madde14 & .58 \\
\hline Madde15 & .57 \\
\hline Madde16 & .56 \\
\hline Madde17 & .54 \\
\hline Madde18 & .52 \\
\hline Madde19 & .50 \\
\hline Madde20 & .47 \\
\hline Madde21 & .46 \\
\hline
\end{tabular}


Özdeğer

b) Doğrulayıcı Faktör Analizi: Doğrulayıcı Faktör Analizi (DFA) için, AMOS 21 paket programı kullanılmıştır (Arbuckle, 2012). DFA, açımlayıcı faktör analizinde elde edilen tek faktörlü modelin doğrulanıp doğrulanmadığını belirlemek amacıyla yapılmıştır. Tablo 2'de İnönü Evlilik Tutum Ölçeği’nin uyum iyiliği indeksleri sunulmuştur.

Tablo 2. İnönü Evlilik Tutum Ölçeği’nin Uyum İyiliği İndeksleri

\begin{tabular}{lcccccccc}
\hline & CMIN & DF & CMIN/DF & GFI & NFI & CFI & RMSEA & RMR \\
\hline $\begin{array}{l}\text { Tek faktörlü } \\
\text { model }\end{array}$ & 499.734 & 172 & 2.905 & .91 & .90 & .93 & .059 & .043 \\
& & & & & & & & \\
\hline
\end{tabular}

Uyum indekslerinden RMSEA için .06 ve SRMR .08 ya da daha az bir değer model için kabul edilebilir uyumun göstergesi olarak kabul edilmektedir (Hu ve Bentler, 1999). CFI, GFI, AGFI uyum indeksleri .90 kabul edilebilir, .95 ve üstü iyi bir uyum indeksi olarak kabul edilir (Hu ve Bentler, 1999; Kelloway, 1998). Tablo 2'de verilen faktör analizi ölçüm değerlerine bakıldığında, 21 maddeli tek faktörlü ölçeğin modele ilişkin $\chi^{2}=499.73 \mathrm{sd}=$ $172, \chi^{2} / s d=2.905$, değerleri saptanmıştır. Bununla birlikte, $\mathrm{CFI}=.93, \mathrm{GFI}=.91, \mathrm{NFI}=.90$ ve $\mathrm{RMR}=.04$ değerleri ile ölçeğin kabul edilebilir uyum değerlerinde olduğu saptanmıştır. Ayrıca, RMSEA'nın .05 değeri ile kabul edilebilir uyum değerine sahip olduğu görülmektedir.

\section{İETÖ’nün Güvenirliğine İlişskin Bulgular}

Tablo 3'de görüldüğü gibi, İnönü Evlilik Tutum Ölçeği'nin güvenirliği, iç tutarlılık, testtekrar test ve testi yarılama güvenirlik yöntemleri ile hesaplanmıştır. Ölçeğe ilişkin hesaplanan iç tutarlılık katsayısı .90 , test-tekrar test güvenirliği ise .87 olarak bulunmuştur. Spearman Brown testi yarılama yöntemiyle elde edilen güvenirlik katsayısı ise .88 şeklindedir. Güvenirlik katsayısının .70 ve üzerinde olması test puanları için yeterli olarak görülmektedir (Büyüköztürk, 2012). Bu bilgiler dikkate alındığında, hesaplanan güvenirlik katsayılarının yeterli olduğu görülmektedir. Ayrıca her maddenin madde-toplam korelasyonuna ilişkin değerler incelendiğinde, bu değerlerin .48 ile .73 arasında değiştiği bulunmuştur. Field (2009), bu değerlerin .30'un altında olmaması gerektiğini belirtmektedir 
ve buna göre ölçek maddelerinden elde edilen puanların toplam puanla kabul edilebilir düzeyde korelasyon gösterdikleri belirlenmiştir.

Tablo 3. İn̈nü Evlilik Tutum Ölçeği’nin Güvenirliğe İlişkin Değerleri

\begin{tabular}{cccc}
\hline & Cronbach Alpha & $\begin{array}{c}\text { Sperman Brown } \\
\text { Testi Yarılama }\end{array}$ & Test-tekrar test \\
\hline İETÖ & .90 & .88 & .87 \\
\hline
\end{tabular}

\section{Tartışma}

$\mathrm{Bu}$ çalışmada genç yetişkinlik döneminde bulunan bireylerin evliliğe ilişkin tutumlarını belirlemek amacıyla geçerli ve güvenilir bir Evlilik Tutum Ölçeği geliştirilmesi amaçlanmış ve yapılan analizler sonucunda 21 maddelik ve 5'li likert türü bir ölçme aracına ulaşılmıştır. Yapılan açımlayıcı faktör analizi sonucuna göre, İETÖ’nün tek boyutlu bir yapıya sahip olduğu belirlenmiştir. Açımlayıcı faktör analizi ile geliştirilmiş İETÖ’nün bir model olarak doğrulanıp doğrulanmadığını test etmek amacıyla doğrulayıcı faktör analizi uygulanmıştır. Yapılan tek faktörlü doğrulayıcı faktör analizi sonuçlarına göre ölçeğin kabul edilebilir uyum değerlerine sahip olduğu saptanmıştır.

Güvenirlik analizleri için yapılan Cronbach Alpha iç tutarlık katsayısı, test-tekrar test güvenirliği ve Spearman Brown testi yarılama testi sonuçlarına göre, İETÖ’nün güvenilir bir ölçme aracı olduğu görülmüştür.

Son zamanlarda evlilik kurumunda ve evlilik rollerine ilişkin tutumlarda meydana gelen değişikliklerden dolayı; evliliğe ilişkin tutumlar üzerine yapılan araştırmalarda son yıllarda artışlar olduğu görülmektedir (Bener ve Günay, 2012; Kılıç ve diğ., 2007; Ondaş, 2007; Türkaslan ve Suleymanov, 2010). Alanyazında evliliğe ilişkin tutumu belirleme yönelik olarak gerçekleştirilen bu çalışmalar incelendiğinde, bu çalışmaların genellikle evliliğin işlevleri, eş seçimi ve üniversite öğrencilerinin gelecekteki evlilik durumlarına ilişkin beklenti ve arzularını özetle evlilik ile ilgili gençlerin görüş ve düşüncelerini belirlemek amacıyla gerçekleştirildiği gözlenmiştir. Bu çalışmalarda elde edilen bilgiler anket tekniği yoluyla elde edilmiştir. Bu anlamda ülkemizde genç yetişkinlerin evliliğe ilişkin tutumlarını belirlemek amacıyla yapılmış bir ölçme aracının olmadığı görülmektedir. Bu alandaki ölçeklerin eksikliğinden dolayı, evlilik tutumu, evlilik beklentileri, inanç ve davranışları arasındaki ilişki yeterince açıklanamamıştır. 
Yurtdışında evliliğe ilişkin tutumu belirleme yönelik olarak gerçekleştirilen çalışmalar incelendiğinde, Braaten ve Rosen (1998), tarafından geliştirilen Evlilik Tutum Ölçeği’nin (ETÖ), İETÖ gibi tek boyutlu olarak geliştirildiği görülmektedir. Üç ayrı ölçek çalışmasını kapsayan ‘Evlilik Ölçeği’ adlı çalışma kapsamında (Rosen ve Park, 2013) geliştirilen Evliliğe İlişkin Genel Tutumlar Ölçeği’nde (İGTÖ) maddeler olumlu ve olumsuz tutum olmak üzere iki faktörü yansıtacak şekilde yazılmıştır; ancak yapılan analizler sonucunda ölçeğin olumlu tutum, olumsuz tutum ve evlilik yönelik duygusal tepkileri, özellikle, korkuları ve kuşkuları belirten korku/şüphe alt faktörü olmak üzere üç boyuttan oluştuğu saptanmıştır. Aslında İETÖ’in yapı geçerliğini belirlemek için gerçekleştirilen faktör analiz sonucunda da ölçeğin üç faktörlü bir yapıya sahip olduğu belirlenmiştir. Ancak, birinci faktörün öz değeri ve açıkladığı varyans oranının yüksek iken ikinci faktörde bu değerlerin oldukça düşük çıkması, buna karşılık ikinci faktör ile sonraki faktörlerin öz değeri arasında yakınlık bulunması, ölçeğin tek boyutluluğunu göstermektedir (Lord, 1980; akt. Çokluk ve diğ., 2012). Faktör sayısına sağlıklı karar vermek için öz değer dışında çizgi grafiği de incelenmiş ve bu doğrultuda tek faktörlü bir yapı için yeniden analizler yapılmıştır ve yapılan analiz sonucunda toplam varyansın \% 36,77'sini açıklayan tek faktörlü bir yapı elde edilmiştir. Sosyal bilimlerde yapılan tek faktörlü ölçek yapılarında \% 30 ve daha fazla oranındaki toplam varyans oranlarının yeterli kabul edildiği belirtilmektedir (Büyüköztürk, 2012).

Hem ETÖ hem de İGTÖ, İETÖ’den farklı olarak hem evli olan hem de daha önce hiç evlenmemiş olan bireyler için kullanılabilecek bir yapıda hazırlanmıştır. Ölçeklerde bulunan maddeler evli olan, daha önce evlenmiş olan veya daha önce hiç evlenmemiş olan yetişkin ve ergenlere uygun olacak şekilde yazılmıştır. Ölçeklerde kişinin mevcut ve gelecekteki evliliğine yönelik duygularına ilişkin maddelerle birlikte, bir bütün olarak evlilik kurumuna yönelik duygular ile ilişkili maddeler de bulunmaktadır. İETÖ ise, daha çok daha önce hiç evlenmemiş olan genç yetişkinlerin bir bütün olarak evliliğe ilişkin tutumlarının yanı sıra gelecekteki evlilik durumlarına ilişkin öznel algılarını belirlemeye yönelik olarak geliştirilmiştir. $\mathrm{Bu}$ farklılıktan dolayı ölçeğin uygulanabileceği grup evlenmemiş genç yetişkinlerle sınırlı kalmıştır.

Elde edilen bulgular doğrultusunda, İETÖ’nün genç yetişkinlerin evliliğe ilişkin tutumlarını belirlemede kullanılabilecek yeterlikte psikometrik özellikler açısından geçerli ve güvenilir bir ölçme aracı olduğu söylenebilir. Ancak, ölçeğin faktör analizi çalışmalarının aynı örneklem grubu üzerinde yapılmış olması bir sınırlılık olarak kabul edilmiş, bu anlamda ölçek ile yapılacak yeni çalışmalarda araştırmacıların kendi örneklemleri üzerinde ölçeğin 
faktör yapısını değerlendirerek kullanmaları önerilebilir. $\mathrm{Bu}$ ölçek farklı üniversitedeki öğrenci gruplarına da uygulanabilir. İlerde yapılacak çalışmalarda araştırmacılar öğrencilerin evlilik tutumunu eş seçimi, romantik ilişki, evlilik ve ilişki doyumu gibi değişkenlerle çalışmanın yanında farklı demografik değişkenlerle de çalışabilirler. Bu çalışma sadece üniversite öğrencileri ile gerçekleştirilmiştir. Ancak bu öğrenci grubunun kendi yaş gruplarındaki tüm gençleri temsil etmeleri mümkün değildir. Bu nedenle daha geniş örneklem grupları ve farklı popülasyondan gençler de dâhil edilerek yapılacak çalışmaların da yararlı olabileceği düşünülmektedir.

Ayrıca bu çalışmada, araştırma kapsamında sadece evli olmayan örneklem üzerinde çalışılmıştır. Bu doğrultuda, İETÖ evli olan bir örneklem grubu ile de karşılaştırılabilir. Araştırmacılar üniversite öğrencilerinin evlilik tutumu üzerine farklı çalışmalar yaparak ilgili alanyazına katkı sağlayabilirler. 


\section{Kaynakça}

Arbuckle, J.L. (2012). IBM SPSS Amos 21user's guide, U.S. Government Users Restricted Rights.

Bener, Ö. ve Günay, G. (2012). Gençlerin evlilik ve aile yaşamına ilişkin tutumları. Karabük Üniversitesi Sosyal Bilimler Enstitüsü Dergisi, 2(1), 1-27

Braaten, E.B. ve Rosen L.A. (1998). Development and validation of Marital Attitude Scale. Journal of Divorce and Remarriage, 29, 83-91.

Büyüköztürk, Ş. (2012). Veri analizi el kitabı. Ankara: Pegem Akademi Yayınları.

Çokluk, Ö., Şekercioğlu, G. ve Büyüköztürk, Ş. (2012). Sosyal bilimler için çok değişkenli SPSS ve LISREL uygulamaları. Ankara: Pegem Akademi Yayınları.

Duran, Ş. (2010). Illişki geliştirme programının romantik ilişki yaşayan üniversite ögrencilerinin iletişim becerileri, çatışma iletişim tarzları ve ilişki istikrarları üzerine etkisinin incelenmesi. (Yayınlanmamış Yüksek Lisan Tezi). Hacettepe Üniversitesi Sosyal Bilimler Enstitüsü, Ankara.

Elkind, D. (1970). Erik Erikson's eight stages of man. New York Times Magazine, April, 8186.

Erikson, E.H. (1977). Childhood and society. London: Paladin Grafton Books.

Field, A. (2009). Discovering statistics using SPSS ( ${ }^{\text {rd }}$ Ed). London: Sage Publishing.

Gorsuch, R. L. (1997). Exploratory factor analysis, its role in item analysis. Journal of Personality Assessment, 68 (3), 532-560.

İşmen, Gazioğlu, A. E (2006). Genç Yetişkinlerin Evlilik ve Aile Hayatına İlişkin Görüşlerinin Değerlendirilmesi. M.Ü. Atatürk Eğitim Fakültesi Dergisi, 23, 107-123.

Güleç, G. (2013). Aile yapısı ve ilişkileri. Eskişehir: Anadolu Üniversitesi Açıköğretim Fakültesi Yayınları.

Hu, L. T. ve Bentler, P. M. (1999). Cutoff criteria for fit indexes in covariance structure analysis: Conventional criteria versus new alternatives. Structural Equation Modeling, 6, 1-55.

Kalkan, M. (2002). Evlilik ilişkisini gelişstirme programının, programa katılan eşlerin evlilik uyumu üzerindeki etkisi. (Yayınlanmamış Doktora Tezi). Ondokuzmayıs Üniversitesi Sosyal Bilimler Enstitüsü, Samsun.

Kalkan, M., ve Kaya, S.N. (2007). Evlilik Öncesi İlişkileri Değerlendirme Ölçeği'nin geliştirilmesi: Geçerlik ve güvenirlik çalışması. Aile ve Sosyal Araştırmalar Genel Müdürlüğ̈ Aile ve Toplum Dergisi, 3(11), 35-40.

Kayhan, Ü. (2011). Aile Yapısı ve İlişkileri. Eskişehir: Anadolu Üniversitesi Açıköğretim Fakültesi Yayınları.

Kayhan, Ü. ve Seçkin, N. (1999). Aile yapısı. Eskişehir: Anadolu Üniversitesi Açıköğretim Fakültesi Yayınları.

Keklik, İ. ve Yıldırım, İ. (2012). Aile terapisi: tarihi -kuram ve uygulamaları. Ankara: PDREM Yayınları.

Kelloway, E. K. (1998). Using LISREL for structural equation modeling. A research guide. CA: Sage Publishing.

Kılıç, D., Kaygusuz, C., Bağ, B., ve Tortumluoğlu, G. (2007). Üniversite öğrencilerinin eş seçimine ve evliliğe ilişkin tutumları. Sağllk ve Toplum Dergisi, 17(1), 32-42.

Koçinoğlu, H. (1991). Sosyo ekonomik düzeyi farklı ailelerin evlilik konusundaki bilgi tutum ve tavırlarının saptanması. (Yayımlanmamış Yüksek Lisans Tezi). Gazi Üniversitesi Sosyal Bilimler Enstitüsü, Ankara. 
Nilforoshan, P., Navidian, A. ve Abedi, A. (2013). Studying the psychometric properties of Marital Attitude Scale. Iranian Journal of Psychiatric Nursing, 1(1), 35-47.

Ondaş, B. (2007). Üniversite öğrencilerinin evlilik ve eş Seçimi ile ilgili görüşlerinin incelenmesi, (Yayımlanmamış Yüksek Lisans Tezi), Gazi Üniversitesi Eğitim Bilimleri Enstitüsü, Ankara.

Özgüven, İ. E. (2009). Evlilik ve aile terapisi. Ankara: PDREM Yayınları.

Rosen, A. ve Park, S. (2013). The Marital Scales: Measurement of intent, attitudes, and aspects regarding marital relationships. Journal of Divorce \& Remarriage, 54(4), 295312.

Seiffge-Krenke, I. ve Gelhaar, T. (2008). Does successful attainment of developmental tasks lead to happiness and success in later developmental tasks? A test of Havighurst's (1948) theses. Journal of Adolescence, 31, 33-52.

Tabachnick, B. G. ve Fidell, L. S. (2001). Using multivariate statistics. Boston: Allyn and Bacon.

Türkarslan, N. ve Süleymanov, A. (2010). Üniversite son sınıf öğrencilerinin evlilik konusundaki görüş ve düşünceleri- Azerbaycan ve Türkiye karşılaştırması. Karadeniz-Blacksea-Черное море, 05, 54-66.

Worthington, R. L.ve Whittaker, T. A. (2006). Scale development research a content analysis and recommendations for best practices. The Counseling Psychologist, 34, 806-838.

Yalçın, İ. (2010). İlişki geliştirme programının üniversite öğrencilerinin ilişki doyum düzeylerine etkisi. (Yayınlanmamış Doktora Tezi). Hacettepe Üniversitesi Sosyal Bilimler Enstitüsü, Ankara.

Yılmaz, T. (2009). Evlilik öncesi ilişkileri geliştirme programının çiftlerin ilişki doyumuna etkisi. (Yayınlanmamış Yüksek Lisans Tezi). Ondokuzmayıs Üniversitesi Sosyal Bilimler Enstitüsü, Samsun. 
Ek:

\section{İNÖNÜ EVLİLIKK TUTUM ÖLÇEĞİ}

Aşağıda evliliğe ilişkin ifadeler yer almaktadır. Hiç bir sorunun doğru veya yanlış cevabı yoktur. Sadece sizin nasıl düşündüğünüz önemlidir. Sizin görüş ve düşüncelerinize karş1lık gelen seçeneği 1'den(hiç katılmıyorum), 5'e (kesinlikle katılıyorum) kadar derecelendirilmiş ölçek üzerinde $(X)$ işareti ile belirtiniz. Lütfen ölçekte bulunan tüm ifadeleri değerlendiriniz. Katılımınız için teşekkür ederiz.

Cinsiyetiniz: K( ) E ( )

Yaşını:

\begin{tabular}{|l|l|c|c|c|c|}
\hline & & & & \\
\hline
\end{tabular}




\begin{tabular}{|c|c|c|c|c|c|c|}
\hline 10 & Evliliğin, neslin devamı için önemli olduğunu düşünürüm. & (1) & (2) & (3) & (4) & (5) \\
\hline 11 & Evlilikle birlikte, kişinin sosyal çevresi genişler. & (1) & (2) & (3) & (4) & (5) \\
\hline 12 & $\begin{array}{l}\text { Evliliğin, bireyin toplum içerisindeki saygınlığını } \\
\text { artırdığını düşünürüm. }\end{array}$ & (1) & (2) & (3) & (4) & (5) \\
\hline 13 & Evlilik, düzenli bir hayat sağlar. & (1) & (2) & (3) & (4) & $(5)$ \\
\hline 14 & Evlilik, gereksiz harcamalar yapmayı engeller. & (1) & (2) & (3) & (4) & (5) \\
\hline 15 & Evlilik, sağlıklı bir cinsel yaşam sağlar. & (1) & (2) & (3) & (4) & (5) \\
\hline 16 & Evlilik, toplum içinde kendimi güvende hissetmemi sağlar. & (1) & (2) & (3) & (4) & (5) \\
\hline 17 & $\begin{array}{l}\text { Evlilik olmadan tamamlanacak bir hayatın eksik olacağını } \\
\text { düşünürüm. }\end{array}$ & (1) & (2) & (3) & (4) & (5) \\
\hline 18 & Evlilik, gelirin planlı kullanılmasını sağlar. & (1) & (2) & (3) & (4) & (5) \\
\hline 19 & Evliliğin, rahat bir hayat sağlayacağını düşünürüm. & (1) & (2) & (3) & (4) & (5) \\
\hline 20 & $\begin{array}{l}\text { Evliliğin her insanın yaşaması gereken bir deneyim } \\
\text { olduğuna inanırım. }\end{array}$ & (1) & (2) & (3) & (4) & (5) \\
\hline 21 & Evliliğin, insanı olgunlaştırdığını düşünürüm. & (1) & (2) & (3) & (4) & (5) \\
\hline
\end{tabular}

